\title{
Pengembangan Bahan Ajar Berbasis Guided Inquiry Pada Materi Fisika Kelas $\mathrm{X}$ Semester 2
}

\author{
Husnul Heni Martina ${ }^{1}$, Baiq Azmi Sukroyanti ${ }^{2}$, Syifaul Gummah ${ }^{3}$ \\ ${ }_{1,2,3}$ Pendidikan Fisika, FSTT Universitas Pendidikan Mandalika, Indonesia
}

\begin{tabular}{l}
\hline \hline Article Info \\
Article history: \\
Article Reseived: 19 July 2021 \\
Publication: 20 July 2021
\end{tabular}

Kata Kunci:

Bahan ajar, Guided Inquiry.

\section{Corresponding Author:}

\section{Husnul Heni Martina}

Pendidikan Fisika, FSTT Universitas Pendidikan Mandalika, Indonesia

E-mail: husnulheny99@gmail.com

\section{PENDAHULUAN}

Fisika merupakan mata pelajaran yang menekankan pada kemampuan untuk memahami konsepkonsep fenomena alam yang terjadi sekaligus menekankan pada kemampuan matematis peserta didik. Pada hakikatnya fisika dibagi menjadi 3, yaitu: fisika sebagai proses, fisika sebagai produk, dan fisika sebagai sikap. Dalam konteks pembelajaran fisika di kelas, Wenno (2008) menjelaskan fisika sebagai mata pelajaran yang diajarkan dan merupakan ilmu pengetahuan alam yang membutuhkan penalaran dengan pola berpikir abstrak untuk menghubungkan suatu teori dengan teori lain, suatu konsep dengan konsep lain, sehingga dalam pembelajaran siswa perlu bertindak secara langsung ke hal yang demikian dan sebagai faktor utamanya adalah melalui kegiatan eksperimen. Marnita (2013) menyatakan bahwa fisika juga harus sesuai dengan hakikat pembelajaran IPA yaitu sebagai produk dan proses. Pada hakikatnya siswa diharapkan lebih aktif dan kreatif menemukan berbagai fakta dan konsep dalam pembelajaran di kelas. Berdasarkan hal tersebut, pembelajaran fisika tidak hanya dilihat dari hasil akhir saja tetapi juga saat proses pembelajaran berlangsung.

Proses pembelajaran akan berjalan lebih optimal apabila memaksimalkan segala bahan ajar yang mendukung peserta didik (Habibi, 2014). Bahan ajar sebagai sarana pelatihan mandiri membantu peserta didik untuk belajar mandiri di luar kelas tanpa atau dengan bantuan seperlunya dari guru (Probosari, 2010). Guru dan siswa sangat membutuhkan sumber belajar dalam proses belajar mengajar. Perlu disadari bahwa salah satu faktor penentu dalam peningkatan mutu pengajaran adalah dengan meningkatkan sumber belajar tersebut. Bahan ajar dapat dibuat dalam berbagai bentuk sesuai dengan kebutuhan dan karakteristik materi ajar yang akan disajikan (Dharmasraya, 2008: 1). Bahan ajar merupakan segala bentuk bahan yang digunakan untuk membantu guru/instruktur dalam melaksanakan kegiatan belajar mengajar (Depdiknas, 2008). Soegianto (Arlitasari, 2013) mengungkapkan bahwa bahan ajar adalah bahan atau materi yang disusun oleh guru secara sistematis yang digunakan peserta 
didik dalam pembelajaran. Berdasarkan alasan tersebut, pendidik hendaknya mengembangkan bahan ajar sesuai dengan rencana pembelajaran.

Undang-Undang Nomor 14 Tahun 2005 tentang Guru dan Dosen yang terdapat pada pasal 8 menyatakan bahwa "Guru wajib memiliki kualifikasi akademik, kompetensi, sertifikat pendidik, sehat jasmani dan rohani, serta memiliki kemampuan untuk mewujudkan tujuan pendidikan nasional". Rifa'i \& Catharina (2012: 7) menjelaskan ada empat kompetensi yang harus dimiliki seorang guru profesional yakni kompetensi pedagogik, kompetensi kepribadian, kompetensi sosial, dan kompetensi profesional. Kompetensi profesional menyatakan bahwa seorang guru harus mengembangkan materi pembelajaran secara kreatif kemudian memanfaatkan teknologi informasi dan komunikasi untuk berkomunikasi serta mengembangkan diri (Prastowo, 2011: 5).

Berdasarkan hasil observasi peneliti, bahan ajar yang digunakan di sekolah sangat terbatas, kegiatan pembelajaran fisika yang dilaksanakan belum bisa memfasilitasi siswa dalam proses pembelajaran. Maas (2004) menemukan bahwa kesulitan belajar disebabkan faktor fasilitas yang belum mencukupi terutama buku-buku literatur atau buku paket; anggapan siswa terhadap mata pelajaran; dan kurang motivasi atau tidak mengetahui bagaimana metode atau cara belajar yang efisien. Nurdin \& Lin (2011:91) menyatakan bahwa "mata pelajaran sains sering dianggap sulit, sangat kompleks, rumit dan sulit dipahami oleh siswa" tidak terkecuali pada mata pelajaran fisika. Siswa beranggapan bahwa mata pelajaran fisika itu sulit untuk dimengerti/dipahami sebab guru menjelaskan materi lebih menekankan rumus daripada konsep di kehidupan sehari-hari sehingga siswa kurang berminat belajar fisika. Siswa juga jarang melakukan kegiatan praktikum yang sebenarnya dengan diadakannya praktikum siswa dapat terlibat secara langsung dalam memperoleh pengalaman dan pengetahuannya sendiri. Hal tersebut menyebabkan siswa menjadi kurang berperan aktif selama proses pembelajaran dan rendahnya rasa percaya diri siswa. Pembelajaran hanya memberi pengetahuan dari guru ke siswa, kegiatan siswa di dalam kelas hanya mendengarkan dan mencatat apa yang disampaikan oleh guru. Hal ini menyebabkan siswa cenderung cepat bosan mengikuti kegiatan pembelajaran yang berlangsung. Salah satu hal yang mendasari permasalahan tersebut adalah kurangnya ketertarikan (minat) siswa dalam mempelajari fisika. Hal ini dapat dilakukan dengan menerapkan metode pembelajaran yang tepat pada saat pembelajaran. Salah satu metode pembelajaran yang tepat untuk melatih jiwa fisikawan adalah guided inquiry atau inkuiri terbimbing.

Amri \& Ahmadi (2010: 88) menjelaskan bahwa dalam guided inquiry siswa diberi kesempatan untuk bekerja merumuskan prosedur, menganalisis hasil dan mengambil kesimpulan secara mandiri, sedangkan untuk menentukan topik, pertanyaan dan bahan penunjang guru hanya berperan sebagai fasilitator. Guided inquiry sangat tepat apabila diterapkan dalam pembelajaran yang berhubungan dengan konsep-konsep. Bakke M Matthew (2013) menyatakan bahwa pembelajaran dengan menggunakan metode guided inquiry memiliki nilai kognitif yang tinggi dibandingkan dengan pembelajaran konvensional. Berdasarkan uraian tersebut, metode pembelajaran guided inquiry tepat apabila diterapkan dalam pembelajaran fisika.

Model inkuiri terbimbing terdiri dari enam fase, yaitu: 1) Menyajikan pertanyaan atau masalah; 2) Membuat hipotesis; 3) Merancang percobaan; 4) Melakukan percobaan untuk memperoleh informasi; 5) Mengumpulkan data; 6) Membuat kesimpulan (Eggen dan Kauchak, 1996). Pada pembelajaran inkuiri terbimbing guru memfasilitasi peserta didik untuk berkolaborasi sehingga peserta didik dapat bekerja sama untuk menyelesaikan masalah (Ambarsari, 2013; Ibrahim, 2012; Maloney \& Simon, 2007).

Berdasarkan uraian di atas, peneliti tertarik mengembangkan bahan ajar dalam sebuah penelitian yang berjudul "Pengembangan Bahan Ajar Berbasis Guided Inquiry pada Materi Fisika Kelas X Semester 2".

\section{METODE PENELITIAN}

Jenis penelitian ini adalah penelitian pengembangan (Research and Development/R\&D), dimana akan dikembangkan suatu produk pembelajaran yang kemudian divalidasi sebagai salah satu produk pendidikan. Produk yang dikembangkan berupa bahan ajar berbasis guided inquiry pada materi fisika kelas X semester 2. Model penelitian yang digunakan adalah model pengembangan ADDIE (Analysis, Design, Development, Implementation, Evaluation). Tetapi pada tahap pengembangan ini digunakan hanya tiga tahap yaitu analisis kebutuhan, desain dan pengembangan. Karena disebabkan kondisi yaitu pandemi (covid-19).

Teknik pengumpulan data yang digunakan dalam penelitian ini adalah sebagai berikut:

1. Lembar Validasi oleh Validator 
Lembar Validasi oleh validator dalam penelitian ini digunakan untuk memperoleh masukan berupa kritik, saran, dan tanggapan terhadap bahan ajar berbasis Guided Inquiry pada materi fisika kelas X semester 2 yang dikembangkan. Untuk mengetahui kevalidan bahan ajar berbasis Guided Inquiry dan instrument yang disusun, lembar validasi diberikan kepada validator, validator memberikan penilaian terhadap bahan ajar berbasis Guided Inquiry dengan memberi tanda centang pada baris dan kolom yang sesuai, menulis butir-butir revisi jika terdapat kekurangan pada bagian saran atau dapat menulis langsung pada naskah bahan ajar berbasis Guided Inquiry.

Validasi bahan ajar berbasis Guided Inquiry dilakukan oleh tiga validator ahli bidang media dan bidang materi (fisika). Lembar validasi yang diamati dalam penilaian berupa lembar validasi bahan ajar berbasis Guided Inquiry. Penilaian validator terhadap bahan ajar terdiri dari 4 kategori yaitu tidak valid (1), cukup valid (2), valid (3), dan sangat valid (4).

2. Teknik Analisis Data

Teknik analisis data pada penelitian ini berupa data deskriptif untuk mendapat angka rata-rata persentase. Teknik analisis data untuk validasi bahan ajar berbasis Guided Inquiry sebagai berikut:

a) Analisis Data Hasil Validasi Bahan Ajar

Analisis data yang diperoleh dari angket uji validasi para ahli digunakan untuk mengetahui kelayakan dan respon siswa terhadap bahan ajar yang dibuat. Angket yang digunakan dalam penelitian ini adalah skala likert yang berperingkat 1-4 digunakan untuk memperoleh pendapat dari validasi para ahli dengan kriteria "Sangat Layak (SL), Layak (L), Tidak Layak (TL), dan Sangat Tidak Layak (STL)”.

Skor setiap alternatif jawaban yang diberikan oleh responden pada pernyataan Tabel sebagai berikut:

- Mengubah skor rata-rata yang diperoleh menjadi nilai dengan kriteria. Hal tersebut dilakukan untuk mengetahui kualitas bahan ajar berbasis Guided Inquiry hasil pengembangan yang awalnya berupa skor di ubah menjadi data kualitatif. Sehingga diperoleh kategori penilaian bahan ajar Berbasis Guided Inquiry dalam tabel berikut:

Tabel 1.1 Kriteria Tingkat Kelayakan dan Revisi Produk

\begin{tabular}{|c|c|c|}
\hline Tingkat Pencapaian (\%) & Kualifikasi & Keterangan \\
\hline $81-100$ & Sangat layak & $\begin{array}{c}\text { Tidak perlu } \\
\text { revisi/valid }\end{array}$ \\
\hline $61-80$ & Layak & $\begin{array}{c}\text { Tidak perlu } \\
\text { revisi/valid }\end{array}$ \\
\hline $41-60$ & Cukup & Revisi/tidak valid \\
\hline $21-40$ & Kurang Layak & Revisi/tidak valid \\
\hline $0-20$ & Sangat Kurang & Revisi/tidak valid \\
\hline
\end{tabular}

Sumber : Suwastono, (2011)

\section{HASIL dan PEMBAHASAN}

Pengembangan bahan ajar berbasis Guided Inquiry menggunakan model ADDIE. Model ADDIE terdiri atas lima tahap, yaitu Analysis, Design, Development, Implementation dan Evaluation. Namun pada tahap pengembangan ini, peneliti hanya menggunakan tiga tahap yaitu analisis, perancangan, dan pengembangan dikarenakan pandemi covid-19. Dengan adanya pembatasan interaksi, Kementerian Pendidikan di Indonesia juga mengeluarkan kebijakan yaitu dengan meliburkan sekolah dan mengganti proses Kegiatan Belajar Mengajar (KBM) dengan menggunakan sistem dalam jaringan (daring).

Berdasarkan analisis dari studi pendahuluan, bahan ajar berbasis Guided Inquiry ini dibutuhkan dalam proses pembelajaran. Namun dalam proses pembelajarannya masih menggunakan buku paket yang ketersediannya terbatas dan belum menerapkan bahan ajar berbasis Guided Inquiry.

Langkah selanjutnya adalah Design (rancangan). Desain bahan ajar ini diawali dengan rancangan konsep bahan ajar berbasis Guided Inquiry, yaitu memilih pendekatan pembelajaran yang digunakan dalam bahan ajar. Setelah merancang konsep, peneliti mempersiapkan referensi pendukung pembuatan bahan ajar. Referensi terdiri atas buku-buku fisika. Kemudian menentukan indikator dari KI dan KD yang sesuai dengan kurikulum 2013.

Tahap ketiga yaitu Development (pengembangan). Pada tahap ini diawali dengan penyusunan draf buku yang akan menjadi acuan dalam mengembangkan bahan ajar berbasis Guided Inquiry. Komponen-komponen di dalam bahan ajar terdiri dari sampul bahan ajar, kata pengantar, deskripsi bahan ajar, panduan penggunaan bahan ajar,daftar isi, peta konsep, materi, lembar kerja siswa, tugas, 
contoh soal, soal evaluasi, daftar pustaka, profil penulis. Bahan ajar t yang dikembangkan yaitu berbasis Guided Inquiry yang sesuai dengan materi yang dibahas.

Dalam penelitian pengembangan ini, dilakukan uji kelayakan produk hasil pengembangan. Uji kelayakan tersebut dilakukan oleh dosen ahli dari UNDIKMA Mataram yang telah berpengalaman selama 5 tahun dalam pembelajaran MIPA. Uji kelayakan dilakukan dengan menggunakan angket. Dalam angket terdapat dua data yaitu data kuantitatif dan data kualitatif. Data kuantitatif berisi pertanyaan-pertanyaan tertulis untuk menentukan tingkat kelayakan produk hasil pengembangan sedangkan data kualitatif berisi tanggapan dan saran perbaikan. Berikut akan disajikan data hasil uji kelayakan dari masing-masing validator dan subjek uji coba.

Tabel 1. 2 Data Kualitatif Hasil Uji Kelayakan Validasi Ahli

\begin{tabular}{|c|c|c|c|}
\hline Validator & Skor perolehan $(\boldsymbol{\%})$ & Kualifikasi & Kriteria \\
\hline Validator 1 & $95 \%$ & Sangat layak & Tidak perlu revisi/valid \\
\hline Validator 2 & $95 \%$ & Sangat layak & Tidak perlu revisi/valid \\
\hline Validator 3 & $80 \%$ & layak & Tidak perlu revisi/valid \\
\hline
\end{tabular}

Berdasarkan hal tersebut, bahan ajar berbasis Guided Inquiry yang peneliti kembangkan dikatakan sesuai. Hal ini terbukti dari hasil validasi menunjukkan bahwa validator 1 dengan persentase 95\% dalam kategori sangat layak, validator 2 dengan persentase 95\% dalam kategori sangat layak, validator 3 dengan persentase $80 \%$ dalam kategori layak. Dari ketiga penilaian validator di atas, dapat disimpulkan bahwa bahan ajar berbasis guided inquiry sangat layak.

Penelitian yang selaras juga dilakukan oleh Herawati (2019) yang berjudul pengembangan perangkat pembelajaran fisika berbasis guided inquiry untuk meningkatkan penguasaan materi dan keterampilan proses sains peserta didik SMA menghasilkan perangkat pembelajaran materi Fluida Statik berbasis guided inquiry berbantuan aplikasi Edmod. Produk yang dikembangkan layak digunakan untuk meningkatkan penguasaan materi dan keterampilan proses sains peserta didik SMA dengan kategori sangat baik. Perangkat pembelajaran yang dikembangkan juga dapat meningkatkan penguasaan materi fisika peserta didik dengan standar gain 0,85 kategori tinggi dan keterampilan proses sains peserta didik dengan standar gain 43,39\% kategori sedang.

Penelitian yang dilakukan oleh Fery Harmanto (2016) yang berjudul pengembangan perangkat pembelajaran IPA model inkuiri terbimbing (guided inquiry) untuk meningkatkan pemahaman konsep siswa SMP menghasilkan perangkat pembelajaran yang valid, praktis, dan efektif untuk meningkatkan pemahaman konsep siswa.

\section{KESIMPULAN}

Berdasarkan penilaian dan pengembangan yang dilakukan peneliti, maka dapat diambil kesimpulan bahwa desain bahan ajar berbasis Guided Inquiry pada materi fisika kelas X semester 2 mengacu pada model ADDIE (Analysis, Design, Develompment, Implementation, dan Evaluation), namun peneliti tidak melakukan Implementation dan Evaluation karena adanya pandemic covid-19 yang tidak memungkinkan untuk melanjutkan tahap Implementation dan Evaluation.

1. Kelayakan bahan ajar berbasis Guided Inquiry pada materi fisika kelas X semester 2 berdasarkan penilaian ahli desain dan ahli materi sebanyak 3 validator. Hasil penilaian validator 1,2 , dan 3 , berturut-turut beserta kategorinya yaitu 95\% (sangat layak), 95\% (sangat layak), dan 80\% (layak). Dengan demikian, produk yang dikembangkan cocok untuk diterapkan sebagai bahan ajar fisika pada kelas X semester 2 .

\section{SARAN}

Berdasarkan pada kesimpulan di atas, maka peneliti mengajukan saran-saran sebagai berikut:

1. Bagi guru, berdasarkan hasil penelitian ini penggunaan bahan ajar Worksheet berbasis Guided Inquiry dapat dijadikan salah satu alternatif media yang digunakan dalam proses pembelajaran.

2. Bagi peneliti selanjutnya, dapat mengembangkan bahan ajar berbasis Guided Inquiry pada pembelajaran fisika dengan kompetensi dasar yang lain serta dapat melanjutkan peneliti ini dengan mengimplementasikan dan mengevaluasikan produk bahan ajar berbasis Guided Inquiry dalam proses pembelajaran.

\section{UCAPAN TERIMAKASIH}

Terima kasih yang sebesar-besarnya penulis sampaikan kepada Baiq Azmi Sukroyanti, M.Pd dan Syifaul Gummah, M.Pd selaku dosen pembimbing. Dr. Habibi, M.Pd., Sukainil Ahzan, M.Si., dan Dwi Pangga 
M.Si sebagai validator, beserta teman-teman seperjuangan yang terlibat dalam proses penelitian, penyutingan hingga penerbit artikel ini dalam Jurnal Pendidikan Fisika, FSTT dan UNDIKMA Mataram.

\section{DAFTAR PUSTAKA}

Ambarsari, W., Santosa, S., \& Maridi. (2013). "Penerapan pembelajaran inkuiri terbimbing terhadap keterampilan proses sains dasar pada pelajaran biologi siswa kelas VIII SMP Negeri 7 Surakarta”. Jurnal Pendidikan Biologi. Vol. 5 No. 1. Januari 2013. pp 81-95.

Amri, S \& Ahmadi K. I. (2012). Proses Pembelajaran Kreatif dan Inovatif dalam Kelas. Jakarta: Prestasi Pustaka Raya.

Aziz Nurdin \& Lin Hui Ling. (2011). Hubungan Mata Pelajaran Sains Dengan Penguasaan Konsep Asas Sains Pelajar Tingkatan Dua. 2 (2231-7368):90.

Darmadi, Hamid. (2014). Metode Penelitian Pendidikan Sosial. Bandung: Alfabeta.

Depdiknas. (2008). Kurikulum Tingkat Satuan Pendidikan. Jakarta : Dikmenum.

Eggen, P., \& Kauchak, D. (1996). Strategies for teacher; teaching content and thinking skills. USA: Allyn and Bacon.

Habibi, M. (2014). Pengembangan Modul Pecahan Berbasis Konstruktivisme Dengan Sisipan Karikatur Untuk Kelas IV Sekolah Dasar. Prosiding Seminar Nasional Pendidikan Matematika. Hal 2748.

Maas, M., (2004). Faktor-Faktor Kesulitan Belajar Akuntansi Siswa IPS SMAK BPK PENABUR Sukabumi. Jurnal Pendidikan Penabur - No.03 / Th.III / Desember 2004 hal 22-49. Diakses di http://www.pdfchaser.com/FaktorFaktor-Kesulitan-Belajar-Akuntansi Siswa-IPS-SMAKBPK-....html Diakses pada tanggal 10 Juni 2021.

Marnita. (2013). Peningkatan Keterampilan Proses Sains melalui Pembelajaran Kontekstual pada Mahasiswa Semester 1 Materi Dinamika. Jurnal Pendidikan Fisika Indonesia. 9 (1): 43-52.

Matthew, B.M. (2013). A Study on the Effects of Guided Inquiry Teaching Method on Students Achievement. International Researchers, 2(1).

Prastowo, A. (2013). Panduan Kreatif Membuat Bahan Ajar Inovatif. Yogyakarta: Diva Press.

Probosari, RM. (2010). Stimulasi Belajar Mandiri Melalui Pengembangan Bahan Ajar Berbasis Masalah Pada Mata Kuliah Plant Embryology And Reproduction (SBI Program) di Prodi P. Biologi FKIP UNS. Seminar Nasional Pendidikan Biologi FKIP UNS 2010. Diperoleh dari: http://eprints.uns.ac.id/14518/1/1298-2917- 1-SM.pdf pada tanggal 10 Juni 2021.

Rifa'i, A \& C. T. Anni. (2012). Psikologi Pendidikan. Semarang: Universitas Negeri Semarang Press.

Suwastono, A. (2011). Pengembangan pembelajaran E-Learning Berbasis Moodle pada Mata Kuliah Penginderaan Jauh SI Jurusan Geografi Universitas Negeri Malang.

Wenno, I.H. (2008). Strategi Belajar Mengajar Sains Berbasis Kontekstual. Yogyakarta: Inti Media. 